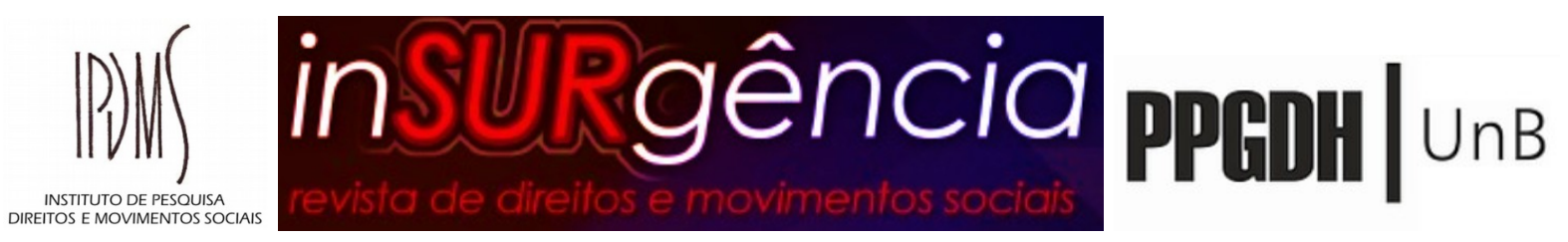

\title{
A DESCOLONIZAÇÃO DOS PATRIMÔNIOS SUBALTERNIZADOS E O RECONHECIMENTO DA INSURGÊNCIA PATRIMONIAL DOS QUILOMBOS NO BRASIL
}

THE DECOLONIZATION OF SUBALTERNIZED HERITAGE AND THE RECOGNITION OF THE KILOMBE'S HERITAGE INSURGENCE IN BRAZIL

Paulo Fernando Soares Pereira ${ }^{1}$

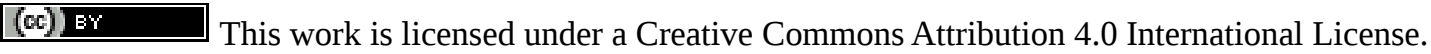

RESUMO: A proposta de artigo tem como objetivo abordar o patrimônio cultural da população quilombola brasileira (comunidades formadas por descendentes de escravizados que fugiam desse processo opressivo) como uma hipótese de descolonização patrimonial. Incluídos na narrativa oficial do Estado Nação ( $5^{\circ}$ do art. 216), em processo relevantíssimo de resistência à escravidão do passado, os quilombos, tiveram a sua contemporaneidade afirmada no art. 68 do Ato das Disposições Constitucionais Transitórias - ADCT, como fenômeno e sujeitos de direitos de um presente que ainda não soube lidar e compensar as dívidas históricas com aqueles que foram vítimas da opressão, da escravidão e do racismo do Estado colonial e imperial brasileiro. Para tanto, a partir de revisão de literatura, o trabalho pretende reafirmar a hipótese decolonial da patrimonialidade quilombola, a partir da necessidade de reconhecimento e inclusão, nas políticas patrimoniais brasileiras, da resistência quilombola aos processos de opressão constituídos pela escravidão, os quais se perpetuam desde a Abolição da escravidão, em 1888. A revisão crítica de literatura antropológica, histórica e jurídica, aliada à análise documental de processos administrativos junto ao IPHAN constituem a metodologia.

Palavras-chave: Quilombos. Resistência. Patrimônio cultural. Contemporaneidade. Decolonialidade patrimonial.

1 Doutor em Direito, Estado e Constituição pela Universidade de Brasília - UnB. Mestre em Direito e Instituições do Sistema de Justiça pela Universidade Federal do Maranhão - UFMA. Graduado em Direito pela Universidade Federal de Roraima - UFRR (2006). É integrante da Advocacia Geral da União - AGU, exercendo o cargo de Procurador Federal.. Email: paulofsp1983@gmail.com. ORCID: https/orcid.org/0000-0001-68029035. 


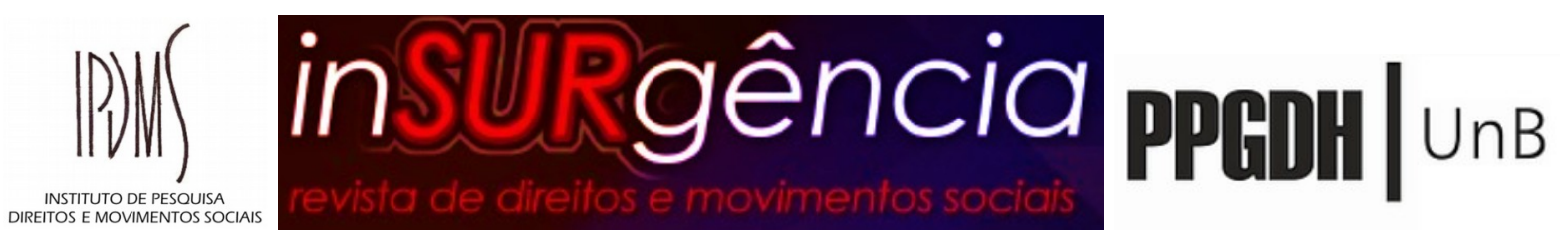

Abstract: The proposed article aims to address the cultural heritage of the Brazilian quilombola population (communities formed by descendants of enslaved people who fled this oppressive process) as a hypothesis of heritage decolonization. Included in the official narrative of the Nation State ( $\S 5$ of art. 216), in a very relevant process of resistance to slavery in the past, the quilombos had their contemporaneity affirmed in art. 68 of the Transitional Constitutional Provisions Act - ADCT, as a phenomenon and subject of rights of a gift that still did not know how to deal and compensate the historical debts with those who were victims of oppression, slavery and racism of the Brazilian colonial and imperial State. Therefore, based on a literature review, the work intends to reaffirm the decolonial hypothesis of quilombola patrimoniality, based on the need for recognition and inclusion, in Brazilian patrimonial policies, of quilombola resistance to the processes of oppression constituted by slavery, which are perpetuated since the Abolition of slavery in 1888. The critical review of anthropological, historical and legal literature, combined with the documentary analysis of administrative processes at IPHAN, constitute the methodology.

Keywords: Quilombos. Resistance. Cultural heritage. Contemporaneity. Heritage decoloniality.

\section{Introdução}

A Constituição Federal do Brasil estabelece que "ficam tombados todos os documentos e sítios detentores das reminiscências históricas dos antigos quilombos” (art. 216, $\S 5^{\circ}$ ). Como a descolonização patrimonial pode contribuir para o reconhecimento de direitos culturais subalternizados, como os dos quilombolas? Questões de memória e conflitos identitários envolvendo a ideia do Estado-Nação têm sido objeto de inúmeros estudos nas Ciências Sociais na América Latina² ${ }^{2}$ tendo espaço inclusive para diversas correntes teóricas ligadas ao campo dos estudos culturais ${ }^{3}$, o que tem contribuído para a compreensão da relação

2 Cf. GARCÍA CANCLINI, Néstor; URTEGA, Maritza (coord.). Cultura y desarrollo: una visión crítica desde los jóvenes. Buenos Aires: Paidós, 2012; GARCÍA CANCLINI, Néstor. Culturas híbridas: estratégias para entrar e sair da Modernidade. São Paulo: EDUSP, 2015.

3 Há posições nos mais diversos sentidos e não foi pretensão deste trabalho categorizar as mesmas, apresentando-se apenas aquelas que influenciaram o pensamento do autor a respeito do tema. No Brasil, por exemplo, a influência de Stuart Hall é bem conhecida, cf. HALL, Stuart. A identidade cultural na pósModernidade. Rio de Janeiro: DP\&A, 2006. Porém, não faltam estudos, nas mais diversas perspectivas, com 


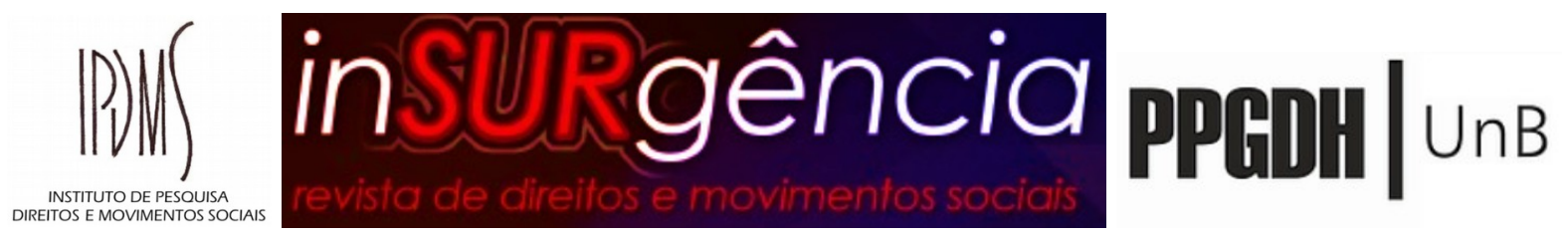

entre sociedade, Estado, Direito e cultura, assim como entender a dinâmica utilizada pelos grupos subalternizados, que tentam ingressar na narrativa construída sobre a ideia da Nação, a fim de saírem das zonas de ocultamento, silenciamento, esquecimento e invisibilidade.

Nesse processo, chegar à proteção pelo sistema jurídico constitui vitória para os grupos subalternizados, pois o campo jurídico possibilita visibilidade e nomeação, induzindo o reconhecimento e inclusão por mais direitos. Portanto, não se trata apenas de reconhecimento de direitos culturais, pois o elemento cultural cria uma espécie de consenso (reconhecimento) sobre direitos negados, à exemplo da diferenciação cultural, que funciona como dispositivo facilitador de inclusão desses direitos para tais grupos.

É nesse sentido que, sob a perspectiva da Constituição Federal de 1988, a ideia de Estado-Nação é enxergada neste trabalho, não como uma possibilidade que deve ser desconstruída, mas remodelada, a fim de reconhecer e incluir os direitos dos diversos sujeitos subalternizados, tendo-se como recorte a questão da inclusão da patrimonialidade quilombola nas representações, símbolos, discursos e ações (políticas públicas) da Nação, ou seja, não se trata de descontruir a Nação, mas de se garantir que os sujeitos subalternizados tenham reconhecidas, através de políticas inclusivas e de gestão, as suas memórias e histórias.

\section{A descolonização patrimonial e direitos culturais subalternizados}

Sobre a ideia de Nação, Stuart Hall argumenta que as culturas nacionais são compostas não apenas de instituições culturais, mas também de símbolos e representações, sendo que uma cultura nacional é um discurso, um modo de construir sentidos que influencia e organiza tanto nossas ações quanto a concepção que temos de nós mesmos (HALL, 2006, p. $50)$.

Para se afirmar, as nações necessitam, dentre outras coisas, de representações, campo do qual emerge o patrimônio cultural, que tem como uma de suas dimensões mais críticas e

essa temática, $c f$. GONZÁLEZ-VARAS IBÁÑEZ, Ignacio. Las ruinas de la memoria: ideas y conceptos para una (im)posible teoria del patrimonio cultural. México: Siglo Veintiuno, 2014; GONZÁLEZ-VARAS IBÁÑEZ, Ignacio. Patrimonio cultural: conceptos, debates y problemas. Madrid: Cátedra, 2015, p. 61-78; MALIGHETTI, Roberto. Arenas identitárias e cidadania: políticas e práticas do confronto. Revista de Políticas Públicas, número especial, p. 181-192, ago. 2010b; POLOUT, Dominique. Uma história do patrimônio no Ocidente, séculos XVIII-XXI: do monumento aos valores. São Paulo: Estação Liberdade, 2009, p. 24-29; RUFER, Mario. Introducción: nación, diferencia, poscolonialismo. In: Nación y diferencia: procesos de identificación y formaciones de otredad en contextos poscoloniales. México: Itaca, 2012, p. 9-43; QUIJANO, Aníbal. Dominación y cultura: notas sobre el problema de la participación cultural. In: QUIJANO, Anibal. Cuestiones y horizontes: de la dependência histórico-estructural a la colonialidade/descolonialidad del poder. Buenos Aires: CLASCO, 2014, p. 668-690. 


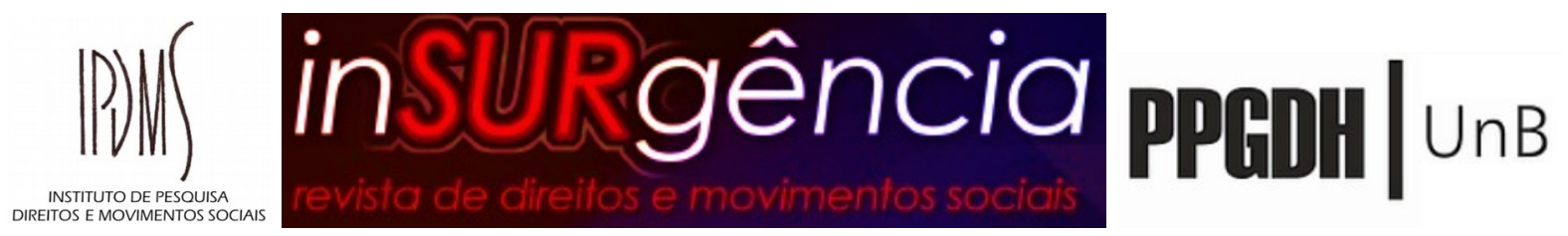

sensíveis a sua capacidade simbólica para a construção da identidade coletiva, pois o patrimônio, além de sua permanência ou presença física e/ou material, é sobretudo uma construção social enquanto seleção simbólica de elementos culturais do passado realizada desde um presente em constante evolução (GONZÁLEZ-VARAS IBÁÑEZ, 2015, p. 63).

Além disso, para Stuart Hall (2006, p. 65), a ideia da Nação como uma identidade cultural unificada não é adequada, pois as identidades nacionais não subordinam todas as outras formas de diferença e não estão livres do jogo de poder, de divisões e contradições internas, de lealdades e diferenças sobrepostas, e, dessa forma, quando se discute se as identidades nacionais estão sendo deslocadas, deve-se entender a forma pela qual as culturas nacionais contribuem para “costurar” as diferenças numa única identidade.

E essa única identidade costuma permear a ideia do Estado-Nação e sua "grande síntese romântica”, através do patrimônio cultural, que é um elemento suscetível de atuar como referente simbólico para construir um discurso hegemônico, o discurso da Nação, todavia, por outro lado, em um processo de descolonização, outras identidades minoritárias, buscam cada vez mais voz, força e legitimação, já que os signos de identidade cultural dos povos subalternizados não podiam ser os mesmos daqueles que foram definidos pelas culturas etnocentradas, ocidentalistas e eurocentradas de cultura e o êxito disso depende em boa medida da coesão que alcançam os elementos simbólicos sobre os que aquele discurso se sustenta (GONZÁLEZ-VARAS IBÁÑEZ, 2014, p. 44 e 65; 2015, p. 29, 37 e 65).

É nesse contexto que, no Brasil, a partir da Constituição Federal (arts. 215 e 216), os povos indígenas e quilombolas estão em contínuo processo de luta para a inclusão na narrativa da Nação, não mais como figuras essencializadas ou caricatas de um passado mítico, mas como sujeitos diversos e diferenciados de uma contemporaneidade múltipla.

Nesse sentido, Ignácio González-Varas Ibáñez (2014, p. 83-85; 2015, p. 64), lembra que o patrimônio cultural tinha como objetivo alcançar a legitimação histórica e cultural da Nação através de um processo de identificação, síntese e absorção que "recuperava” o passado, mas esse processo quase sempre anulava as expressões consideradas subalternas da cultura ou que não se adequavam a grande síntese do Estado-Nação; a institucionalização do patrimônio nacional era a garantia de uma leitura do passado que conduzia a afirmar o projeto de futuro, isto é, que afirmava valores de progresso, desenvolvimento, emancipação e liberdade que sustentavam o projeto moderno, mas este último foi radicalmente questionado e 


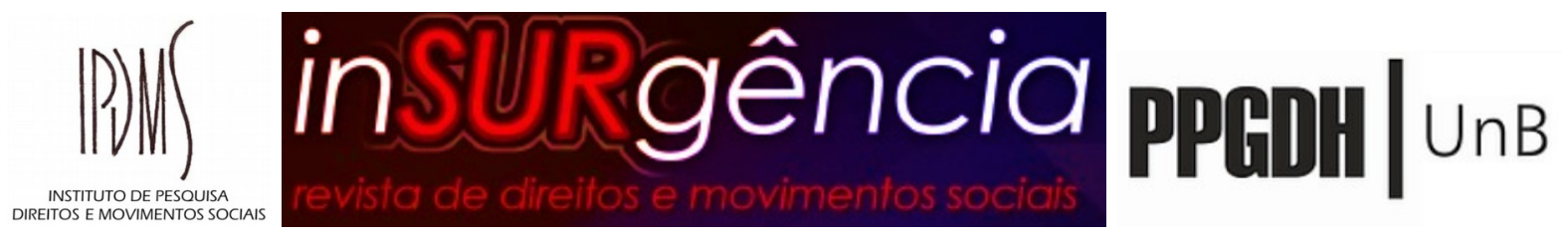

perdeu legitimidade em sua realização histórica mediante a produção de seus contrários, ou seja, seus contra valores, patrimônios dissidentes ou subalternizados.

\section{Descolonizando o patrimônio ou domesticando as insurgências?}

Ao processo de insurgência a essa Nação que apresenta uma ideia romântica de homogeneidade ou que usa as diferenças apenas como álibi de dominação e controle do processo de produção e distribuição dos direitos, pode-se falar em descolonização patrimonial, que pode ser considerado o processo pelo qual a patrimonialidade de sujeitos subalternizados/dissidentes é reconhecida e incluída na agenda de políticas públicas dos órgãos e entidades estatais que lidam com o patrimônio, tendo como pressuposto a garantia de voz ativa a tais sujeitos, não se podendo tratar de mera retórica simbólica impressa no texto constitucional, ao estabelecer que,

Art. 215. O Estado garantirá a todos o pleno exercício dos direitos culturais e acesso às fontes da cultura nacional, e apoiará e incentivará a valorização e a difusão das manifestações culturais.

$\S 1^{\circ}$ O Estado protegerá as manifestações das culturas populares, indígenas e afrobrasileiras, e das de outros grupos participantes do processo civilizatório nacional.

$\S 2^{\circ}$ A lei disporá sobre a fixação de datas comemorativas de alta significação para os diferentes segmentos étnicos nacionais.

$\S 3^{\circ}$ A lei estabelecerá o Plano Nacional de Cultura, de duração plurianual, visando ao desenvolvimento cultural do País e à integração das ações do poder público que conduzem à: [EC no 48/2005]

I - defesa e valorização do patrimônio cultural brasileiro; [EC nº 48/2005]

II - produção, promoção e difusão de bens culturais; [EC nº 48/2005]

III - formação de pessoal qualificado para a gestão da cultura em suas múltiplas dimensões; [EC n ${ }^{\circ}$ 48/2005]

IV - democratização do acesso aos bens de cultura; [EC n ${ }^{\circ} 48 / 2005$ ]

V- valorização da diversidade étnica e regional. [EC n ${ }^{\circ} 48 / 2005$ ]

Art. 216. Constituem patrimônio cultural brasileiro os bens de natureza material e imaterial, tomados individualmente ou em conjunto, portadores de referência à identidade, à ação, à memória dos diferentes grupos formadores da sociedade brasileira, nos quais se incluem:

I - as formas de expressão;

II - os modos de criar, fazer e viver;

III - as criações científicas, artísticas e tecnológicas;

IV - as obras, objetos, documentos, edificações e demais espaços destinados às manifestações artístico-culturais;

V - os conjuntos urbanos e sítios de valor histórico, paisagístico, artístico, arqueológico, paleontológico, ecológico e científico.

$\S 1^{\circ}$ O Poder Público, com a colaboração da comunidade, promoverá e protegerá o patrimônio cultural brasileiro, por meio de inventários, registros, vigilância, tombamento e desapropriação, e de outras formas de acautelamento e preservação. $\S 2^{\circ}$ Cabem à administração pública, na forma da lei, a gestão da documentação governamental e as providências para franquear sua consulta a quantos dela necessitem. 


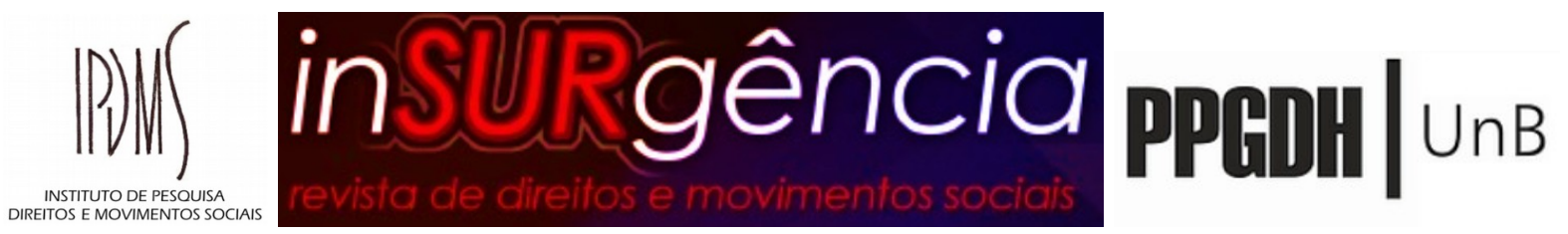

$\S 3^{\circ}$ A lei estabelecerá incentivos para a produção e o conhecimento de bens e valores culturais.

$\S 4^{\circ}$ Os danos e ameaças ao patrimônio cultural serão punidos, na forma da lei.

$\S 5^{\circ}$ Ficam tombados todos os documentos e os sítios detentores de reminiscências históricas dos antigos quilombos. [Grifou-se]

Sem a efetiva participação de tais sujeitos (“a comunidade”: indígenas, quilombolas, dentre outros), no processo cíclico de tais políticas públicas, em todas as suas fases (montagem da agenda, formulação da política, tomada de decisão, implementação da política e avaliação), não é possível falar em descolonização do patrimônio nacional.

Não se pode perder de vista que o transplante do modelo de Estado-Nação europeu para a América Latina ${ }^{4}$ respaldou um processo de criação de um tipo específico de homogeneização cidadã, com uma cultura produzida a partir da lei, e a ideia muito difundida de “uma Nação, uma cultura, uma língua e, às vezes, uma religião”, tem funcionado geralmente como um enunciado hegemônico que ocultou uma série de mecanismos que intentaram implementar formas específicas de racialização excludente, modalidades de heteronormatividade de gênero, manutenção do patriarcado no Direito e formações peculiares do discurso liberal, o que possibilitou uma retórica de direitos que apregoa a igualdade jurídica $^{5}$ mesmo quando as condições materiais dos sujeitos não permitem tal igualação (RUFER, 2012, p. 21-22). Portanto, enxerga-se no texto constitucional brasileiro uma série de possibilidades de descolonização patrimonial, pois a constitucionalização da cultura teve preocupação em afirmar e incluir a culturalidade de todos os grupos formadores da Nação (art. 215, § $1^{\circ}$, da CF), o que inclui, também, os novos sujeitos em fluxos e diásporas contemporâneas, como os novos imigrantes.

No sentido acima, percebe-se a possibilidade da patrimonialidade quilombola ser tida/construída como uma hipótese de patrimônio decolonial (art. 216, § 5º da CF), caso, efetivamente, seja dado voz aos sujeitos subalternizados pelo processo de colonização

4 A questão gestão cultural e do patrimônio na América Latina é profícua em discussões nas mais diversas perspectivas teóricas, cf. CASTELLANOS V., Gonzalo. Patrimonio cultural: integración y dessarrollo en América Latina. Bogotá: Fondo de Cultura Económica, 2010; DUSSEL, Enrique. Oito ensaios sobre cultura latino-americana e libertação. São Paulo: Paulinas, 1997, p. 1-94; GARCÍA CANCLINI, Néstor. O porvir do passado. In: Culturas híbridas: estratégias para entrar e sair da Modernidade. São Paulo: EDUSP, 2015, p. 159-204; GRIMSON, Alejandro. Los límites de la cultura: crítica de las teorías de la identidad. Buenos Aires: Siglo Veintiuno, 2015; HERMET, Guy. Cultura e desenvolvimento. Petrópolis: Vozes, 2002; VELASCO MAILLA, Honorio; PRIETO DE PEDRO, Jesús (eds.). La diversidad cultural: análisis sistemático e interdisciplinar de la Convención de la UNESCO. Madrid: Trotta, 2016; VICH, Victor. Desculturizar la cultura: la gestión cultural como forma de acción política. Buenos Aires: Siglo Veintiuno, 2014.

5 No Brasil, tal previsão está no art. 5, caput, da CF de 1988, e já era prevista desde a Constituição Imperial, de 1824 (art. 179, XIII): “A Lei será igual para todos, quer proteja, quer castigue, o recompensará em proporção dos merecimentos de cada um". 


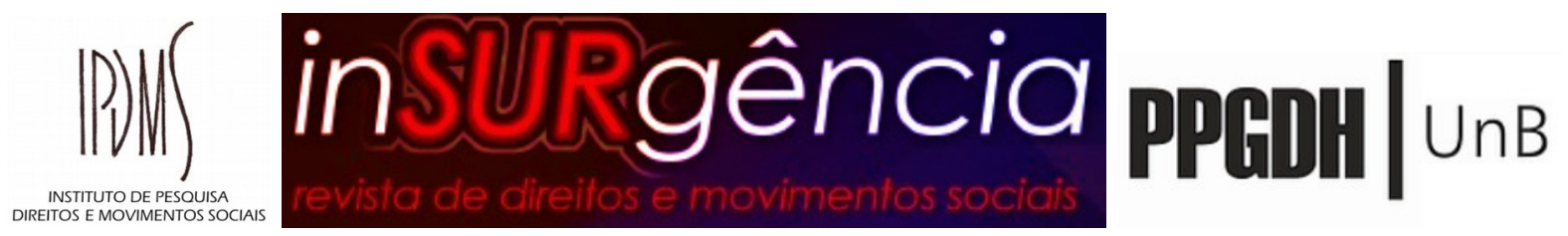

brasileiro. Esse reconhecimento jurídico da patrimonialidade dos sítios remanescentes dos antigos quilombos é importante não apenas para a difusão da contribuição dos mesmos na construção de direitos (no passado, a liberdade; na atualidade, a igualdade, a inclusão etc.), inclusive quando tais direitos se apresentam negados pela própria ordem jurídica, mas porque demonstra que a conquista de direitos é fruto das lutas políticas dos sujeitos interessados/subalternizados que superam os burocratismos das esferas formais e o negativismo da sociedade conservadora envolvente, daí o reconhecimento e a inclusão de "todos os documentos e os sítios detentores de reminiscências históricas dos antigos quilombos” na Constituição Federal, através da figura do tombamento (art. 216, § 5º).

A patrimonialidade quilombola subverte aquilo que se denominou de naturalização das diferenças do Estado-Nação, pois as formações discursivas que fundamentaram povo-Naçãocultura-cidadania-Estado, além de serem altamente eficazes na construção de aparatos legais que objetivaram relações históricas, tiveram um efeito mais poderoso, naturalizaram essa historicidade, fazendo-a aparecer como necessária, e ainda universalizou um processo particular da união Estado-Nação (RUFER, 2012, p. 22), representada principalmente na teoria social, incorporada ao discurso burocrático e das elites, de que o Brasil se constituiu em uma democracia racial e que, portanto, "todos são iguais perante a lei, sem distinção de qualquer natureza” (art. 5º, caput, da CF), não sendo necessárias medidas reparadoras para aqueles que sofreram ou que descendem do processo de escravização.

Assim, os quilombos, para nossa história constitucional, contribuem evidenciando que o povo, de forma coletiva e, às vezes anônima, pode/deve ser construtor de sua trama e dos seus direitos, traçando os fios de sua História (SEGATO, 2014), demonstrando-se que esta última não é comandada apenas pelos heróis escolhidos pela representação da "grande síntese romântica da Nação” (GONZÁLEZ-VARAS IBÁÑEZ, 2015, p. 37).

Ainda que o Estado-Nação tenha tratado em sua etapa de nascimento e formação de anular as diferenças e absorver a diversidade dentro de uma suposta unidade cultural, agora, a Nação, caso queira persistir, deve aceitar sua condição cultural inevitavelmente plural e diversa, pois as nações se compõem em identidades múltiplas, difusas e particulares, tencionando-se a homogeneidade e eficácia institucional e administrativa do Patrimônio Cultural Nacional (GONZÁLEZ-VARAS IBÁÑEZ, 2014, p. 95).

Portanto, a formulação da ideia do Estado-Nação tem importante função na produção da memória social no contexto dos países que sofreram o processo de dominação colonial, 


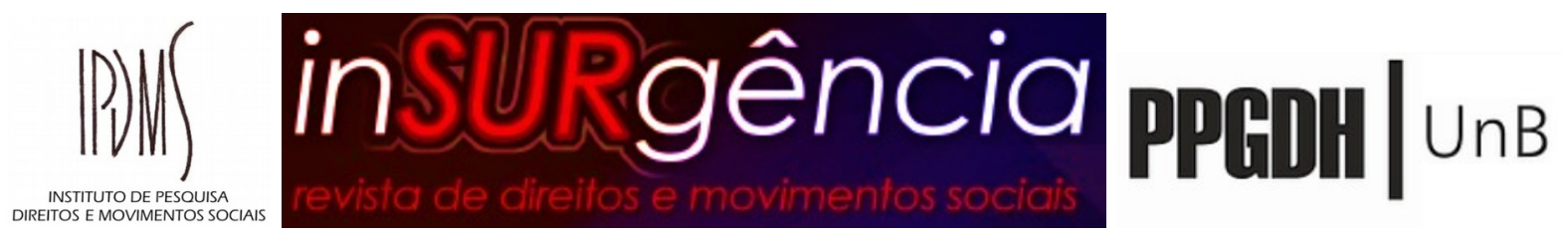

seja em um passado mais distante ou recente, pois essa memória é objeto de disputas e negociações, boa parte das vezes normatizadas pelo Direito, através da disciplina dos direitos culturais e através da patrimonialização das memórias selecionadas para representar a Nação, em detrimento daquelas que serão silenciadas.

\section{A construção da ideia de Estado-Nação e a produção da memória social}

Nesse sentido, utilizou-se do pensamento do historiador argentino, radicado no México, Mario Rufer, a respeito da instituição de memória social. A produção de Mario Rufer, objeto de diversos artigos e livros ${ }^{6}$, é considerado como um dos trabalhos mais interessantes dentro da produção latino-americana sobre as políticas de memória e a respeito dos usos públicos da História, tendo em vista que o historiador faz uma discussão teórica aprofundada sobre a produção da memória social e sua relação com a formação do Estado-Nação moderno (VARGAS ÁLVAREZ, 2014, p. 1), especialmente em contextos pós-coloniais, o que não exclui a possibilidade de se aplicar tal discussão em contextos coloniais, como o Brasil, fazendo-se as devidas ponderações.

Para tanto, Mario Rufer utilizou os componentes tradicionais da historiografia, da antropologia histórica, dos estudos da memória, subalternos e pós-coloniais, e se interessou em identificar os processos de produção de sentido sobre o passado, suas tensões e contradições durante as três últimas décadas, dos contextos pós-coloniais ${ }^{7}$ caracterizados pela emergência de políticas de memória e processos de justiça de transição no qual se tem colocado em jogo múltiplas leituras sobre a história no espaço público (VARGAS ÁLVAREZ, 2014, p. 1).

Desse modo, a tese central do seu principal livro $^{8}$ é constituída de dois elementos: primeiramente, sustentando-se que os registros são como produções de história atravessadas por profundas lutas para a representação do passado; no segundo elemento, ditas produções da

6 Não há traduções de seus livros, no Brasil, em que pese algumas publicações de artigos, em espanhol, principalmente. Suas obras principais obras são: RUFER, Mario. Reinscripciones del pasado: nación, destino y poscolonialismo em la historiografia de África Occidental. Ciudad de México: El Colegio de México, 2006; . La nación en escenas: memoria pública y usos del pasado en contextos coloniales. Ciudad de México: El Colegio de México/Centro de Estudios de Asia y África, 2010b; Nación y diferencia: procesos de identificación y formaciones de otredad en contextos poscoloniales. Ciudad de México: Itaca, 2012. 7 Cf. RUFER, Mario. La memoria como profanación y como pérdida: comunidad, patrimonio y museos en contextos poscoloniales. A Contra corriente: estudios latinoamericanos, vol. 15, n 2, p. 149-166, winter 2018. $8 C f$. La nación en escenas: memoria pública y usos del pasado en contextos coloniales. Ciudad de México: El Colegio de México, 2010b. 


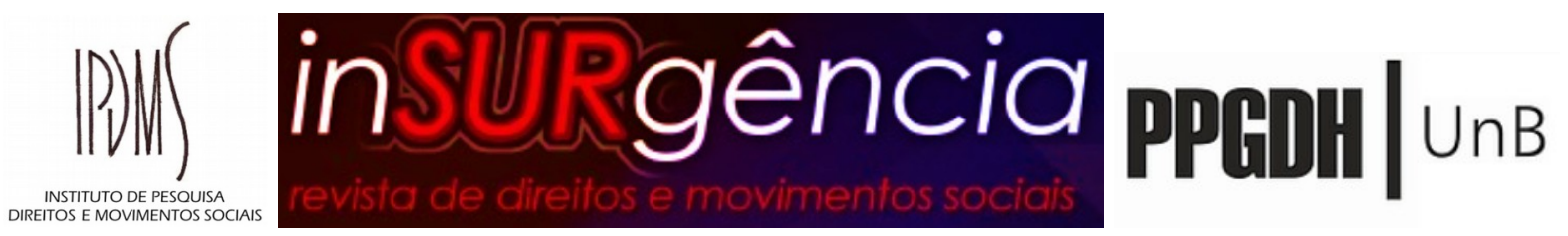

história refletem complexas confrontações pela redefinição do passado desde o Estado Nacional e desde setores subalternizados, depois de eventos históricos traumáticos, citando-se como exemplos significativos o apartheid sul-africano e a ditadura militar argentina (VARGAS ÁLVAREZ, 2014, p. 2). Aqui, é interessante notar que, no Brasil, a escravidão, evento mais traumático de nossa história é encarada apenas como fato superado do passado, o que dificulta bastante as discussões em torno de políticas de recuperação e valorização da memória para a população afro-brasileira. Mesmo assim, considera-se que a patrimonialidade quilombola, prevista na Constituição Federal de 1988 (art. 216, § 5º), é um exemplo disso, como algo que pode ser construído, a partir do que denominamos de política patrimonial antirracista.

Mario Rufer (2010, p. 15) adverte que as histórias das nações latino-americanas mostram que a Modernidade dessa parte do continente é uma forma interativa do discurso colonizante a partir da posição das elites crioulas que mudaram o discurso político para a realização nacional e na narrativa histórica dos países pós-coloniais, o sujeito "cidadão" corresponde, geralmente, a um indivíduo falido, em transição, racializado, “mestiço”, sendo uma abstração das temporalidades múltiplas de mundos e vidas divergentes, sintetizado em uma imagem uniforme de uma Nação homogênea e independente.

Mas como se cria essa imagem sobre o passado? Quem tem a oportunidade de fala sobre esse passado e essas memórias? Nesse ponto, o historiador indaga a respeito de quem tem a faculdade e a autoridade de falar sobre o passado nos registros discursivos da história e da memória, dando como exemplos significativos disso o caso do apartheid sul-africano ${ }^{9}$ e do movimento indígena argentino ${ }^{10}$ (RUFER, 2011).

Quem fala por quem no discurso que constitui e constrói a narração do passado? Quem pode falar? Como se configura o lugar donde se autoriza o discurso sobre o

9 Atualmente, na África do Sul, não se trataria apenas da exclusão racializada do apartheid, mas a exclusão dos pobres da democracia, havendo poucos processos políticos com luta tão significativa sobre o passado como o sul-africano pós apartheid, em que a história pública, através de memórias, museus, monumentos, cerimônias e festivais, tem cobrado uma atenção máxima (RUFER, 2011, p. 17-18); Cf. também, NDLOVU-GATSHENI, Sabelo. Coloniality of power in postcolonial Africa: myths of decolonization. Dakar: Codesria, 2013; NDLOVU-GATSHENI, Sabelo. El movimento estudiantil "Rhodes debe caer" (Rhodes Must Fall): las universidades sudafricanas como campo de lucha. Tabula Rasa: Revista de Humanidades, n 25, p. 195-224, 2016 ${ }^{\text {a }}$ RUFER, Mario. Monuments, museums and re-articulation of nation: pedagogies, performances and subaltern apprehensions of memory. Intercultural Communication Studies (ICS), vol. XVI, no . 2, p. 158-177, 2007.

10 No caso argentino, o autor trata das razões pelas quais o movimento indígena, após a ditadura militar, passou atuar no campo da ação política para ver reconhecido o seu papel na história da Argentina; segundo o movimento indígena, considera-se que o "terrorismo de estado" se situava com a violência genética do estado nacional, inaugurada com a "Conquista do Deserto", momento no qual a formação do Estado-Nação se consolidou com a expropriação das terras indígenas e o extermínio de seus povos com o "fim da fronteira” (RUFER, 2011, p. 32). 


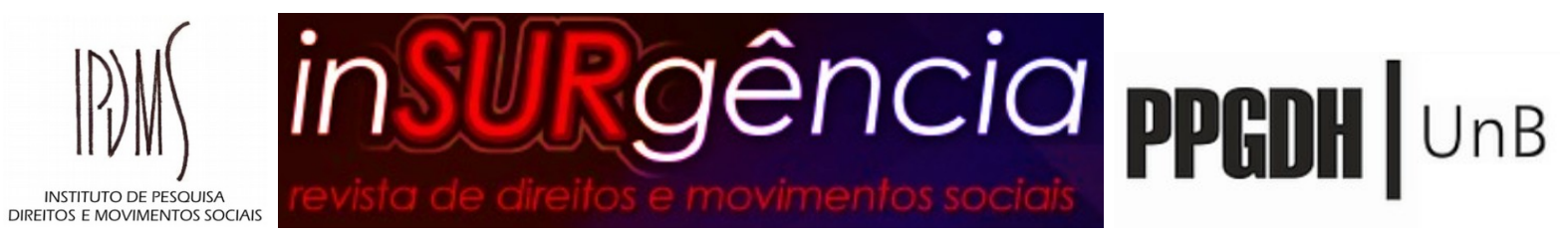

passado, encarnado na produção de história? Estas são grandes perguntas que recorrem a análise do discursos histórico e histórico-antropológico dos últimos 40 anos no Ocidente (RUFER, 2011, p. 21)

Citando o filósofo Jacques Derrida (2001), lembra que há uma disposição moderna de monumentalizar, isto é, de reconverter resquícios do passado em evidências, junto à atitude de conservar, que vem desde a preservação colecionista dos antiquários do século XIX até a atual fixação pós-moderna das políticas patrimoniais ${ }^{11}$ (RUFER, 2011, p. 23-24).

Assim, a produção discursiva sobre a experiência social passada e presente, não implica necessariamente em uma produção de verdade, a menos que nosso único espaço de reflexão seja a Europa hiper-real, devendo-se tomar consciência de que a Europa, como sujeito teórico colonizador, não é somente um continente delimitado territorialmente, mas uma ideia que se propaga eficazmente, e como tal, alastra-se nos Estados Unidos e parte de alguns redutos institucionais e sociais da América Latina (RUFER, 2011, p. 27).

Todavia, ao se reconhecer formas diversas de narrar a experiência no tempo, continua-se reproduzindo essa localização problemática entre a diacronia das sociedades quentes e o presente etnográfico das sociedades frias (RUFER, 2011, p. 29). Sobre esse ponto, dando como exemplos os casos dos museus comunitários, no México, Mario Rufer (2014c, p. 106), diz que:

Não é novidade que as formas de patrimonialização local emanam muitas vezes de réplicas do Estado-Nação transformadas em demandas de autogestão que são apropriadas por localidades específicas (e com resultados diferentes) [...] Partindo daqui, considero que é válido dizer que toda análise dos museus oficiais (que dependem diretamente de braços institucionais do Estado) deve ser feita sob uma lupa onde poética e política não podem se desligar (e nunca como amostra de uma pegada indicial de um acontecimento já passado). Porém, os museus comunitários devem ser analisados com mais cuidado ainda. Não somente porque pela minha análise é errado argumentar que são um complexo exibitório de tradições conservadas, práticas comunitárias deslegitimadas pela Modernidade ou qualquer outro argumento romantizado sobre a identidade e a memória, mas porque, ademais, devem ser estudados dentro do complexo processo de hibridação com as pedagogias do Estado.

Dessa forma, Mario Rufer (2014c, p. 108) argumenta que é preciso desconfiar dos processos formativos de patrimonialização local inclusive, devendo-se escapar a visões romantizadas do patrimônio comunitário (um ponto que pode servir de alerta ao processo de patrimonialização dos quilombos), porque são justamente essas noções nativistas e

11 Sobre a obsessão patrimonial, cf. CHOAY, Francoise. A alegoria do patrimônio. São Paulo: Estação Liberdade - UNESP, 2006; TAMAZO, Izabela M. Por uma distinção dos patrimônios em relação à história, à memória e à identidade In: PAULA, Zuleide Casagrande et al. Polifonia do patrimônio. Londrina: EDUEL, 2012, p. 21-45. 


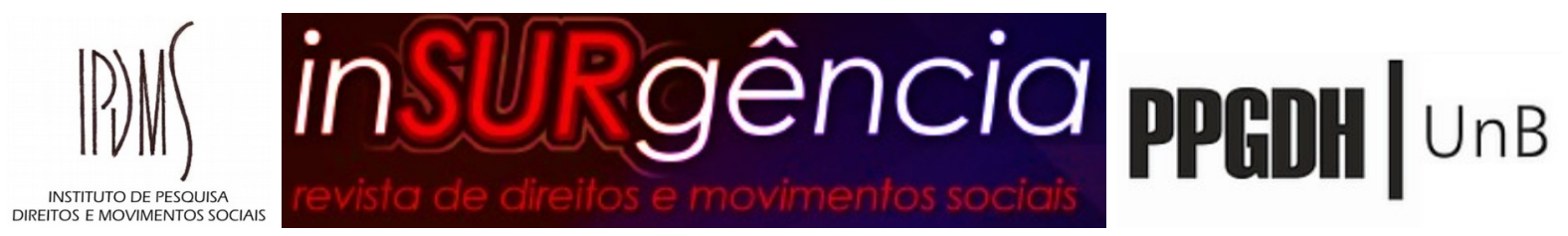

românticas, não raras vezes bem intencionadas, que perpetuam as hierarquias, assimetrias e axiologias que o Estado-Nação moderno e excludente tem estabelecido como uma luta silenciosa por recursos para não reconhecer as diferenças, as pluralidades e as diversidades. Autores como Peter Wade (2003) e Jocélio Teles dos Santos (2005) já haviam chamado atenção para esse fato, seja na Colômbia ou no Brasil, nas oportunidades as quais o EstadoNação se vale da apropriação da cultura negra para reforçar o mito fundacional e obter dividendos à custa da exploração do turismo étnico etc.

Dessa forma, utilizando a tese de Bárbara Krishenblatt-Gimblett (1998), Mario Rufer (2014c, p. 106) argumenta que, ao se considerar a cultura como um "recurso", tem-se mostrado a modalidade de ativação que há nos processos de patrimonialização, quando são exitosos, para se pôr em marcha noções nativistas de tradição, memória e identidade como partes de processos mais amplos de promoção ao turismo, desenvolvimento sustentável e ofertas de sentido do tempo e a experiência local.

Nesse contexto, a paisagem aparece como um monumento construído e ligado a um passado grandioso que já não é, mas que deve exibir-se como o fundamento político do presente e defesa de um futuro imaginado, possível; seguindo esse raciocínio, pode-se dizer que a noção de patrimônio tangível ou intangível, proposta pela UNESCO, esquece um elemento central, o qual significa que a patrimonialização é uma construção social símbolo de uma promessa de futuro; as metáforas de resgate, seja de ruínas, vestígios, mas, igualmente, de línguas, costumes e tradições, no patrimônio local ou comunitário não funcionam somente como um dever cívico que repousa em uma ideia mais ou menos consensual de memória coletiva (há necessidade de se cuidar, conservar, visibilizar); esse resgate ativo sobre toda a ideia de uma promessa detentora de onde a visão teleológica historicista permanece intacta, mas geralmente potencializada por um componente mágico (RUFER, 2014c, p. 114).

Portanto, não raras vezes, a estratégia narrativa esconde a dinâmica da História e de suas contradições, como o despojo, a violência, a transformação daqueles que nestes ocidentes foram oprimidos (o indígena atual, empobrecido, apontado ao lugar de carência e racializado, acrescentando-se, ao Brasil, as comunidades quilombolas), surgindo, por outro lado, a invenção da paisagem como patrimônio-memória, no qual monumentos, revolução, língua, etnia, funcionam como fundamento-promessa ao que se pode outorgar esse status (RUFER, 2014c, p. 115). Então, o que se propõe nesse cenário um tanto desalentador no qual tudo parece conspirar contra a retirada das zonas de silenciamento das memórias subalternizadas? 


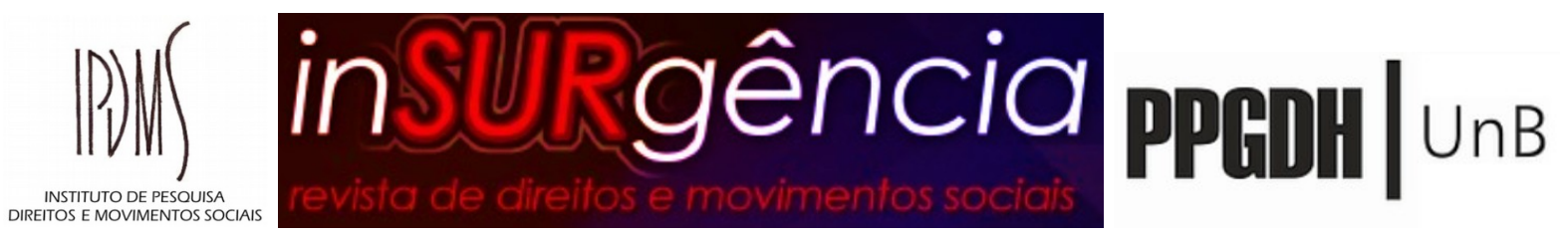

\section{Memória sem garantias}

Normalmente, hoje, a narração autorizada sobre a história, nessa voz que regula as ruínas desde outro lugar e escolta os sujeitos no tempo, reconhecem-se visivelmente dois elementos: a) as origens monumentalistas da disciplina, ligada ao positivismo como corrente e ao Estado-Nação europeu como contexto político; b) a existência de outras fontes (RUFER, 2011, p. 29). Em um momento de perversa funcionalidade da produção do “outro”, as fontes históricas da diversidade correm o risco de produzir a voz que se anuncia a nosso personagem inicial; correm risco de marcar e tutelar o caminho pré-fixado do sujeito teórico e político (a Europa hiper-real, o Estado-Nação na era global) e manter incólumes as assimetrias em sociedades altamente desiguais na produção, distribuição e acesso ao conhecimento, e também ao acesso aos bens simbólicos e processos que legitimam os discursos/recursos culturais (RUFER, 2011, p. 38).

Mario Rufer (2011, p. 35), dessa forma, propõe que a História necessita revitalizar não somente a contingência de seus próprios modos de produção de discurso, ou seja, não apenas reconhecer a conivência do relato e a autoridade com as constituições das culturas coloniais/nacionais, mas, também, deve aspirar a uma política de recuperação, a qual deve promover um compromisso epistêmico de restituição, não somente a restituição da voz dos silenciados, mas sobre toda uma historicidade das estratégias sociais e comunitárias de apropriação, adaptação, negociação e contestação das forças epistêmicas de poder/saber. Como fazer isso, superando-se a opinião decorrente do conforto da crítica acadêmica?

Uma das estratégias possíveis para lidar com a dependência acadêmica e com o problema de reconhecimento da historicidade do processo autoritativo (ou a historicidade da racionalidade historicista, toda vez que o lugar de fontes alternativas está mais ou menos alcançado na academia da História) é fazer evidentes a essas contingências no próprio processo de escrita; deve-se assumir que os protocolos que supõem a verdade histórica são sempre reformulados e que os binarismos, como fontes orais/escritas, relatos históricos/narrações, pensamento mágico/secular, são categorias/entidades criadas mas que 


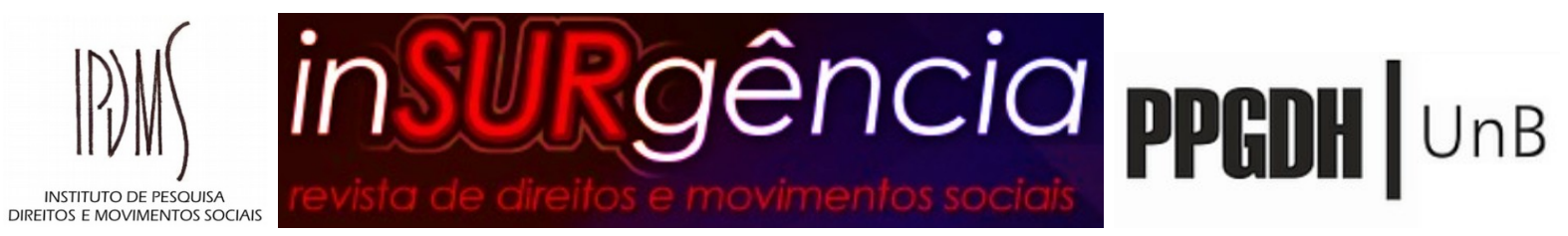

operam e constituem os mundos sociais (RUFER, 2011, p. 35; 2013, p. 107). Esses binarismos costumam esconder a dualidade, tratada por Rita Laura Segato (2012, p. 123), para quem:

\begin{abstract}
O dualismo, como o caso do dualismo de gênero no mundo indígena, é uma das variantes do múltiplo. O número dois resume e representa uma multiplicidade referida ou resultante dos trânsitos entre os dois polos; os cruzamentos, encontros e encruzilhadas das tantas formas de transgeneridade constatadas nos mundos não interferidos ou somente parcialmente interferidos pela estrutura da colonialidade. O binarismo, próprio do mundo do Um do colonial / Modernidade, resulta da episteme do expurgo e da exterioridade que o sistema colonial construiu e a colonialidade mantém vigente. $\mathrm{O}$ um e o dois que formam a dualidade indígena são uma entre muitas possibilidades do múltiplo, e ainda que possam funcionar em complementaridade, são ontologicamente completos e cada um é dotado da sua própria politicidade, apesar de desiguais em valor e prestígio. O segundo nessa dualidade hierárquica não constitui um problema que necessita conversão, não é mister submetê-lo a um processamento pela grade do equivalente universal, e tampouco é resto da transposição para o Um, mas é plenamente outro, um outro completo, irredutível (SEGATO, 2012, p. 123).
\end{abstract}

Propõe-se, portanto, uma memória sem garantias, como uma nova forma de escrever a História, sendo uma crítica as dicotomias poder/potesta, colaboração/resistência, expondo-se as conivências da histórica como disciplina na perpetuação de uma narrativa "garante” da razão fundacionista: tais narrativas apontam a persistência de orientações analíticas que deixam pouco espaço para a ambivalência, a contradição e a contingência como pressupostos sociológicos mas também epistemológicos, recuperando-se o subalterno e evitando-se que a fixação “do outro lado” seja apenas uma possiblidade de reproduzir involuntariamente as formas de colonialidade da História, por meio dos quais se reforça e reifica o canônico/regulado/normativo (RUFER, 2011, p. 36-37), através da fetichização do tempo. Sobre isso, Mario Rufer (2010, p. 19) diz que o tempo é fetichizado, como forma de hierarquias os sujeitos, negando-se contemporaneidade a povos e comunidades tradicionais.

\begin{abstract}
A Nação fetichiza o tempo como sua exterioridade a fim de objetivar o destinoprogresso. A Nação ocidental é a singularidade que permite falar de um desenvolvimento do povo no tempo: uma experiência política que está subsumida na história que narra, e que encontra no progresso a fábula principal de sua extensão espaço-temporal. A identidade entre tempo se torna uma façanha: é necessário 'mostrar' o arcaico para ressaltar a Modernidade, o atavismo é parte da primeira política nacional da memória.
\end{abstract}

O mito da origem da Nação funda uma dupla negação: não reconhece a certos indivíduos como sujeitos da Modernidade, como povos indígenas ou comunidades quilombolas, e como a História não pode deixar de reconhecer as condições contingentes de produção desse discurso. O vazio que funda o salto entre a grandeza da tradição e a 


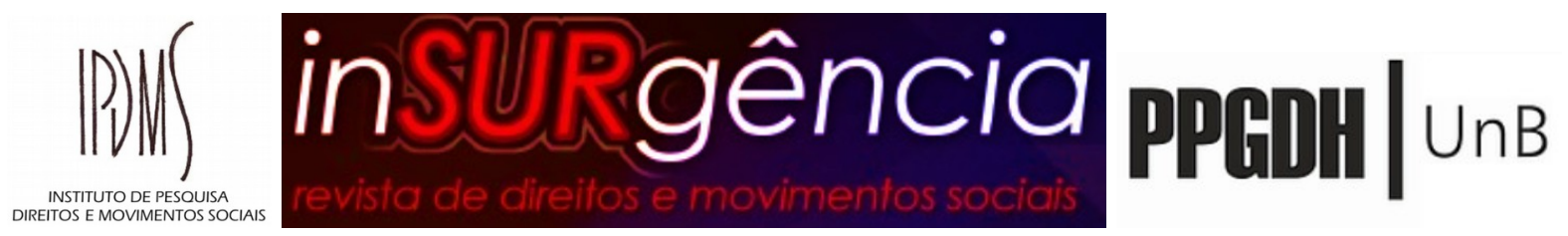

subjetividade nacional moderna pretende sepultar qualquer continuidade na produção orquestrada de material do despojo material e simbólico de grande parte do "povo”; e separa os “sujeitos da Nação”, possuidores de direitos, das “comunidades menores” pré-modernas (RUFER, 2010, p. 21), as quais têm a sua contemporaneidade negada: povos indígenas, quilombolas e outros povos e comunidades tradicionais.

Logicamente, nesse raciocínio, a cidadania é negada, de fato, para uma grande parte do “povo”, como substrato da Nação, evidenciado no Brasil, principalmente pela exclusão da população indígena e negra da partilha dos direitos. Por outro lado, essa negação não se justifica como um mecanismo histórico de despojo, racialização, segmentação e engenharia biopolítica, mas como uma condição daqueles que teriam sido deixados de fora da História e com quem a missão pendente é o "resgate", a modernização e a "sala de espera" do desenvolvimento, sempre falho e atrasado (RUFER, 2010, p. 22), decorrente do alcance de uma ilusão meritória engenhosa e estruturalmente inalcançável.

Esses sujeitos “outros” (os indígenas, os nativos, os camponeses, os quilombolas, no Brasil) ficaram à espera de um duplo processo de negação simbólica em grande parte dos discursos acadêmicos e políticos: por um lado, subsumidos sob a lógica do capital no desenvolvimento da Nação, enquanto desprovidos dos benefícios de ordem sistêmica do capitalismo; por outro lado, dispostos na ordem da tradição atávica como mostra das origens, mas despojados do terreno de enunciação da história-destino nacional (RUFER, 2010, p. 22). Ao questionar a razão pela qual a memória dos “outros” não costuma fazer parte da ideia de Nação e relacionar o tempo com a diversidade, Mario Rufer (2010, p. 25) lembra que:

Para que se produza eficazmente a noção de progresso no tempo e para a criação pedagógica da imagem nacional do progresso, são indispensáveis três condições: um observador invisível privilegiado (Europa e seu tempo transposto para a América e mais tarde a África como forma de atraso), uma origem possível de ser naturalizada e domesticada no contínuo temporal a partir de estratégias específicas de discurso, e uma tradição que deve ser mantida como valoração mas sobretudo como a distância, o que Benjamim chamou de 'arcaização' do tempo-mercadoria (que estávamos e que nos permitiu ser, mas não estamos mais).

Assim, um dos problemas cruciais da noção de patrimônio, seja das iniciativas governamentais ou dos processos e atores sociais, está relacionado com a persistência de uma noção “culta” de cultura como parte do “acervo patrimonial” (RUFER, 2014, p. 111-112), que, no Brasil, pode ser muito bem representada pela proeminência do denominado “patrimônio material” de origem luso-brasileira e da folclorização da cultura negra e indígena, tidas, para muitos, como atrasadas, presas ao passado (ideia de reminiscências ou 


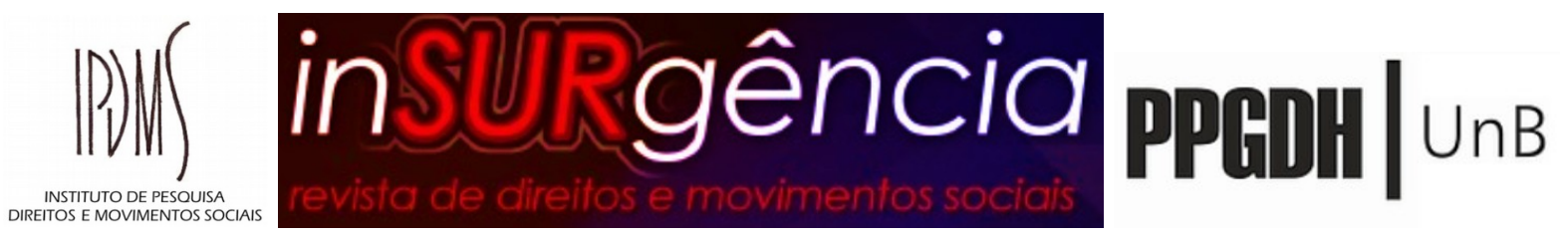

remanescente presente no próprio texto constitucional brasileiro), incultas e um tanto insepultas, representadas através do "patrimônio imaterial”.

Mario Rufer (2014, p 113-114) argumenta que o objeto cultural, exibido em uma série de distinções e de classificações tipológicas, sofre perdas importantes: de objeto que faz sentido em uma paisagem local a objeto que faz sentido em uma unidade maior (o patrimônio nacional), qualificando-se essa operação como a persistência da “colonialidade”, como aparato de enunciação que define e representa, que segue estando operado pela tutela do Estado-Nação com matrizes da Modernidade colonial.

Em contextos latino-americanos e, especificamente, no México ${ }^{12}$, a noção de "patrimônio nacional” segue amarrando esse procedimento cirúrgico e a eficácia atual de "o nacional” se reflete no poder altamente ritualizado de instituições centralizadas e museus nacionais $^{13}$ (RUFER, 2014, p. 116), o que não é muito diferente no Brasil com suas instituições que não encaram o racismo institucional e cultural que exclui os povos indígenas e a população negra, como quilombolas, de parte significativa da patrimonialização.

Esse silêncio foi o lugar dos demais silêncios que são reproduzidos: o do excluído nas políticas culturais, o silêncio dos próprios povos ante a celebração do patrimônio que não pode/não quer fazer uma memória dos processos de despatrimonialização, de parcialidade de seus ambientes paisagísticos da Nação, o silêncio sobre a dificuldade de narrar uma memória comum que não seja a pedagogia nacionalista instaurada com mecanismos que forjaram uma ideia de localidade, Modernidade e tradição em tensão (RUFER, 2014b, p. 13-14).

\section{Conclusão: da transformação da História em lei à restituição da voz dos silenciados}

Se se voltar à ideia de História como saber, como produção de um efeito coercitivo, o problema não é somente a consideração do arquivo como uma forma de conhecimento política e institucionalmente condicionado e organizado, como uma emanação de poder;

12 No caso mexicano, o discurso da diversidade cultural e da mestiçagem excluiu os processos históricos de diferenciação e hierarquização, uma vez que omitiu mencionar que a diversidade foi um enunciado que marcou a Nação de um lugar de enunciação preciso: o Estado, devendo-se insistir na poderosa espiritualidade imaginada, sendo o discurso da mestiçagem um ponto cego que segue funcionando como referente central para garantir um axioma, cujo núcleo nacional é o "mestiço"; o restante é diversidade, que resulta expulso, outra vez, o indígena e sua historicidade, em seu componente histórico de negociação e resistência (RUFER, 2014c, p. 126-127).

13 A museologia é um campo com diversas discussões que se inter-relacionam com o patrimônio. Sobre museus, inclusive a relação dos museus nacionais como representação do Estado Nacional, $c f$. NASCIMENTO JUNIOR, José do. Economia de museus. Brasília: MinC/IBRAM, 2010; POLOUT, Dominique. Museo y museología. Madrid: Abada Editores, 2011, p. 30-32, 51-52, 56, 77. 


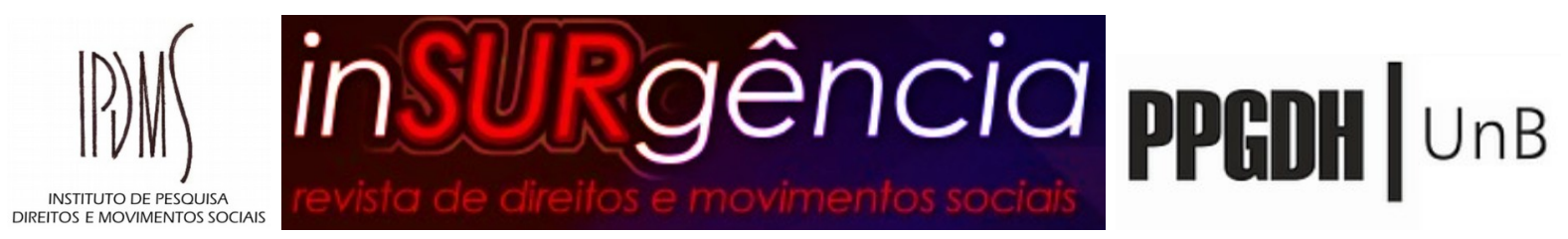

tampouco se trata de considerar simplesmente que existem narrações e metodologias alternativas para compreender processos históricos, indo-se além da predisposição de privilegiar as fontes escritas nos protocolos cotidianos do trabalho em História (RUFER, 2013, p. 95).

Dessa forma, algo presente no pensamento de Mario Rufer é a afirmação segundo a qual há uma violência para fundar a lei na História ${ }^{14}$, uma violência que institui autoridade não por deixar de fora somente uma determinada quantidade de “evidência confiável”, mas por excluir formas de produzir sentido sobre o passado que partem de um conceito diferente de verdade, mostrando-se irônico que cada vez mais seja necessário afirmar que a história da verdade depende da articulação dos discursos, dos argumentos, e do consenso alcançado na comunidade de historiadores: o espaço da regulação de saberes, do disciplinamento e da “violência que persiste para conservar a lei” (RUFER, 2011, p. 31; 2013, p. 101).

Dever-se-ia poder promover no Sul um compromisso epistêmico de restituição, mas não somente uma restituição “da voz dos silenciados”, cuja possibilidade em sentido estrito, é duvidosa, mas uma restituição sobre toda uma historicidade das estratégias sociais e comunitárias de apropriação, adaptação, negociação e contestação das forças epistêmicas do poder/saber (RUFER, 2013, p. 107).

Restituir pressupõe equidade e a democracia produzida pela equidade refere-se à perspectiva de reconhecimento, espaço de diferença, pertencimento, consenso e negociação, tudo isso traduzido em direitos. Nesse sentido, uma certificação que tem esse objetivo implica em fortalecer os espaços em que sujeitos possam construir mediações, expressar suas opiniões e disputar aspectos que envolvem cristalizadas formas de encapsular o poder (FARRANHA, 2014, p. 111).

Portanto, a restituição dessas vozes silenciadas requer que se reconheça "nos outros" as suas memórias e histórias. No campo patrimonial brasileiro, o reconhecimento da patrimonialidade quilombola é um dos caminhos para a concretização desse ideal, tendo em vista se tratar de um dos mais representativos exemplos da contribuição da população negra, com sua insurgência à opressão da escravidão, para a História do Brasil.

Frantz Fanon (2008, p. 180) argumenta que o conceito de reconhecimento se dá através do "outro", que, igualmente, aguarda nosso reconhecimento. Entretanto, nem sempre

14 Pensadores de uma tradição hegemônica e eurocentrada, também, já falam da violência do Estado-Nação. $C f$. GIDDENS, Antony. O Estado-Nação e a violência: segundo volume de uma crítica contemporânea ao materialismo histórico. São Paulo: EDUSP, 2008. 


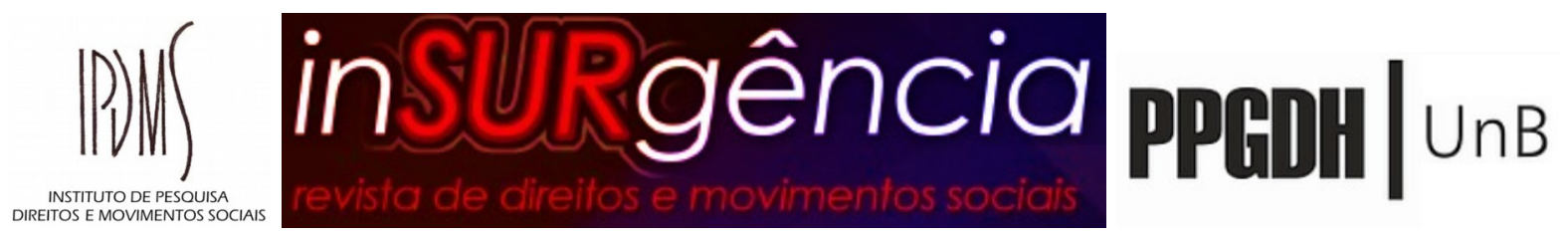

esse encontro com “os outros" resulta em reconhecimento, podendo resultar em subalternização, a qual, com a proteção do Direito, no caso do patrimônio, hierarquiza e racializa as diferenças.

Dessa forma, o trabalho objetivou tratar do processo de reconhecimento da patrimonialidade negra no sistema de representação da Nação brasileira, procurando demonstrar que tal processo não está imune à racialização das diferenças. O sistema jurídico, protetor desse sistema de representação, através do instituto do tombamento, proporcionou argumentos de negação ao discurso que não reconhecia patrimonialidade aos exemplares da cultura dos povos indígenas e da população negra.

Através do processo de luta, a negação patrimonial foi combatida, permitindo-se reconhecer, inclusive através do tombamento, o Terreiro Casa Branca como patrimônio cultural do Brasil, o qual ressignificou aquele instituto jurídico, fissurando o sistema de representação da Nação e permitindo que outros exemplares pudessem ser, igualmente, reconhecidos sob a tutela jurídica.

Mais recentemente, já em nível internacional, o reconhecimento pela UNESCO, do Cais do Valongo como Patrimônio Mundial demonstra que as discussões sobre os efeitos da escravidão não se esgotaram e que continuam atuais. Essas discussões permitem afirmar que o reconhecimento de bens culturais dissidentes, como a quilombola, pode constituir exemplos aptos a descolonizar o patrimônio.

\section{Referenciais}

CASTEllanOS V., Gonzalo. Patrimonio cultural: integración y dessarrollo en América Latina. Bogotá: Fondo de Cultura Económica, 2010.

CHOAY, Francoise. A alegoria do patrimônio. Tradução de Luciano Vieira Machado. 4. ed. São Paulo: Estação Liberdade - UNESP, 2006.

DUSSEL, Enrique. Oito ensaios sobre cultura latino-americana e libertação. Tradução de Sandra Trabucco Valenzuela. São Paulo: Paulinas, 1997.

DERRIDA, Jacques: Mal de arquivo: uma impressão freudiana. Tradução de Cláudia de Moraes Rego. Rio de Janeiro: Relume Dumará, 2001.

FANON, Frantz. Pele negra, máscaras brancas. Tradução de Renato da Silveira. Salvador: EDUFBA, 2008.

FARRANHA, Ana Cláudia. Equidade e Participação: percurso na construção de um programa de governo. Revista Observatório Brasil da Igualdade de Gênero. Brasília: Secretaria de Políticas para as Mulheres, p. 97-112, abr. 2014. 


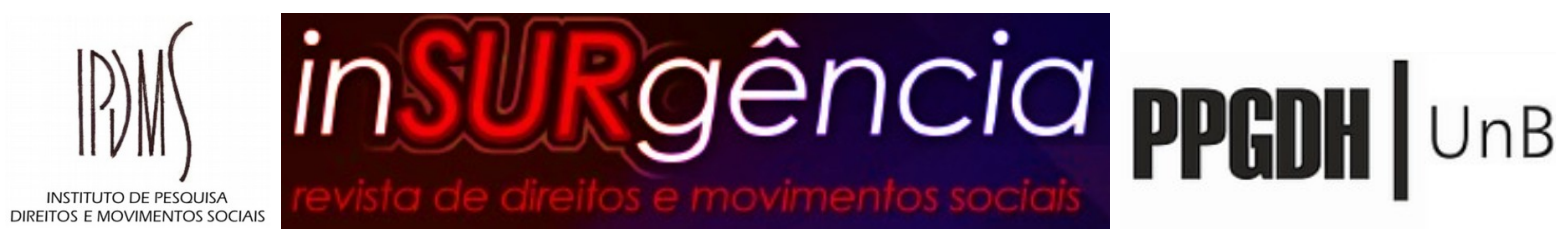

GARCÍA CANCLINI, Néstor; URTEGA, Maritza (coord.). Cultura y desarrollo: una visión crítica desde los jóvenes. Buenos Aires: Paidós, 2012.

GARCÍA CANCLINI, Néstor. Culturas híbridas: estratégias para entrar e sair da Modernidade. Tradução de Ana Regina Lessa et al. 4. ed. São Paulo: EDUSP, 2015.

GIDDENS, Antony. O Estado-Nação e a violência: II volume de uma crítica contemporânea ao materialismo histórico. Tradução de Beatriz Guimarães. São Paulo: EDUSP, 2008.

GONZÁLEZ-VARAS IBÁÑEZ, Ignacio. Las ruinas de la memoria: ideas y conceptos para una (im)posible teoria del patrimonio cultural. Ciudad de México: Siglo Veintiuno Editores, 2014.

Patrimonio cultural: conceptos, debates y problemas. Madrid: Ediciones Cátedra, 2015.

GRIMSON, Alejandro. Los límites de la cultura: crítica de las teorías de la identidad. Buenos Aires: Siglo Veintiuno, 2015.

HALL, Stuart.A identidade cultural na pós-modernidade. Tradução de Tomaz Tadeu da Silva e Guacira Lopes Louro. 11. ed. Rio de Janeiro: DP\&A, 2006.

HERMET, Guy. Cultura e desenvolvimento. Tradução de Vera Lúcia Lúcia Joscelyne. Petrópolis: Vozes, 2002.

KIRSHENBLATT-GIMBLETT, Barbara. Destination culture: tourism, museums, and heritage. Berkeley: University of California Press, 1998.

MALIGHETTI, Roberto. Arenas identitárias e cidadania: políticas e práticas do confronto. Revista de Políticas Públicas, São Luís (UFMA), número especial, p. 181-192, ago. 2010b.

NASCIMENTO JUNIOR, José do. Economia de museus. Brasília: MinC/IBRAM, 2010.

NDLOVU-GATSHENI, Sabelo. Coloniality of power in postcolonial Africa: myths of decolonization. Dakar: Codesria, 2013.

El movimento estudiantil "Rhodes debe caer" (Rhodes Must Fall): las universidades sudafricanas como campo de lucha. Tabula Rasa: Revista de Humanidades, Bogotá (Universidad Colegio Mayor de Cundinamarca), nº 25, p. 195-224, $2016 a$.

POLOUT, Dominique. Uma história do patrimônio no Ocidente, séculos XVIII-XXI: do monumento aos valores. Tradução de Guilherme João de Freitas Teixeira. São Paulo: Estação Liberdade, 2009.

POLOUT, Dominique. Museo y museología. Traducción de Juan Calatrava. Madrid: Abada Editores, 2011.

QUIJANO, Aníbal. Dominación y cultura: notas sobre el problema de la participación cultural. In: QUIJANO, Anibal. Cuestiones y horizontes: de la dependência históricoestructural a la colonialidade/descolonialidad del poder. Buenos Aires: CLASCO, 2014, p. 668-690.

RUFER, Mario. Reinscripciones del pasado: nación, destino y poscolonialismo em la historiografia de África Occidental. Ciudad de México: El Colegio de México, Centro de Estudios de Asia y África, 2006. 


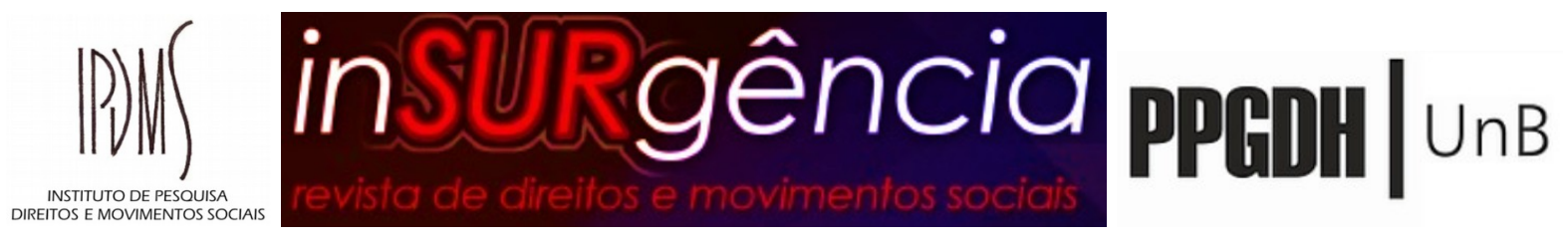

Monuments, museums and re-articulation of nation: pedagogies, performances and subaltern apprehensions of memory. Intercultural Communication Studies (ICS), Kingston (University of Rhode Island), vol. XVI, nº 2, p. 158-177, 2007.

La temporalidad como política: nación, formas de pasado y perspectivas poscoloniales. Memoria y Sociedad, Bogotá (Pontificia Universidad Javeriana), vol. 14, $\mathrm{n}^{\circ}$ 28, p. 11-31, ene./jun. 2010.

La nación en escenas: memoria pública y usos del pasado en contextos coloniales. Ciudad de México: El Colegio de México, Centro de Estudios de Asia y África, 2010b.

. La memoria de los otros: sulbaternidad, poscolonialismo y regímenes de verdade. REALIS: Revista de Estudos AntiUtilitaristas e PosColoniais, Recife (UFPE), vol. 1, $\mathrm{n}^{\circ}$ 01, p. 13-43, jan./jun. 2011.

RUFER, Mario. Introducción: nación, diferencia, poscolonialismo. In: RUFER, Mario (org.). Nación y diferencia: procesos de identificación y formaciones de otredad en contextos poscoloniales. Ciudad de México: Itaca, 2012, p. 9-43.

Experiencia sin lugar en el lenguaje: enunciación, autoridad y la historia de los otros. Revista Relaciones: estudios de historia y sociedad, Zamora de Hidalgo (El Colegio de Michoacán, México), vol. 133, p. 79-115, invierno. 2013.

La exhibición del otro: tradición, memoria y colonialidad en museos de México. Antíteses, Londrina (UEL), vol. 7, nº 14, p. 94-120, jul./dez. 2014.

La comunidad melancólica. Etnicidad, patrimonio comunitario y memoria en México. KLA Working Paper Series, Bielefeld (Bielefeld Universität, Alemanha), vol. 12, p. 1-21. 2014b.

Paisage, ruina y nación. Memoria local e historia nacional desde narrativas comunitarias en Coahuila. Cuicuilco: Revista de Ciencias Antropológicas, México (Instituto Nacional de Antropología e Historia - INAH), vol. 21, nº 61, p. 103-136, sep./dic. 2014c.

RUFER, Mario. La memoria como profanación y como pérdida: comunidad, patrimonio y museos en contextos poscoloniales. A Contra corriente: una revista de estudios latinoamericanos, Raleigh (North Caroline State University), vol. 15, nº 2, p. 149-166, winter 2018.

SANTOS, Jocélio Teles dos. O poder da cultura e a cultura do poder: a disputa simbólica da herança cultural negra no Brasil. Salvador: EDUFBA, 2005.

SEGATO, Rita Laura. Gênero e colonialidade: em busca de chaves de leitura e de um vocabulário descolonial. E-cadernos CES [On-line], Epistemologias feministas: ao encontro da crítica radical, Coimbra (Universidade de Coimbra), nº 18, p. 106-131, 2012.

SEGATO, Rita Laura. Que cada povo teça os fios da sua história: o pluralismo jurídico em diálogo didático com legisladores. Direito.UnB: Revista de Direito da Universidade de Brasília, vol.1, nº 01, p. 65-92, jan./jun. 2014.

TAMAZO, Izabela. A expansão do patrimônio: novos olhares sobre velhos objetos, outros desafios... Sociedade e Cultura, Goiânia (UFG), vol. 08, nº 02, p. 13-36, jul./dez. 2005.

VARGAS ÁLVAREZ, Sebastián. Reseña del libro: Mario Rufer. La nación en escenas. Memoria pública y usos del pasado em contextos poscoloniales. Intersticios Sociales: revista 


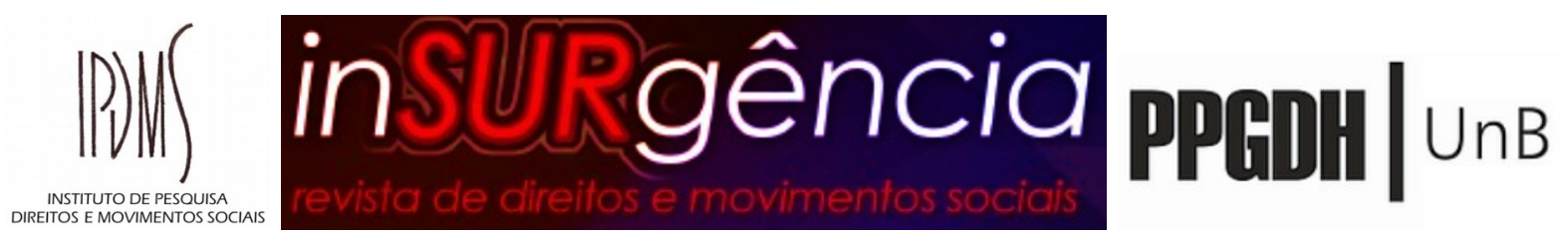

Semestral de Ciencias Sociales y Humanidades, Zapopan (El Colegio de Jalisco, México), ano 4, no 8, sep. 2014.

VELASCO MAILLA, Honorio; PRIETO DE PEDRO, Jesús (eds.). La diversidad cultural: análisis sistemático e interdisciplinar de la Convención de la UNESCO. Madrid: Editorial Trotta, 2016.

VICH, Victor. Desculturizar la cultura: la gestión cultural como forma de acción política. Buenos Aires: Siglo Veintiuno Editores, 2014.

WADE, Peter. Compreendendo a “África” e a “negritude” na Colômbia: a música e a política da cultura. Estudos Afro-Asiáticos, Rio de Janeiro (UCAM), ano 25, nº 1, p. 145-178, 2003.

Submetido em 17/02/2020.

Aprovado em 30/07/2020. 